\title{
PENGARUH BENTUK RANSUM KOMPLIT TERHADAP KONSUMSI DAN KECERNAAN BAHAN KERING DAN BAHAN ORGANIK PADA SAPI BALI
}

\author{
Jamila Mustabi, Amir Mirzad, dan Rinduwati \\ Fakultas Peternakan Universitas Hasanuddin - Makassar \\ e-mail: jamila@unhas.ac.id
}

\begin{abstract}
ABSTRAK
Ransum dapat dinyatakan berkualitas apabila mampu memberikan seluruh kebutuhan nutrien secara tepat, baik jenis, jumlah, serta imbangan nutrien bagi ternak. Penelitian ini bertujuan untuk mengetahui pengaruh bentuk pakan komplit terhadap konsumsi dan kecernaan bahan kering dan bahan organik pada sapi bali. Penelitian ini menggunakan 9 ekor sapi bali yang dibagi menjadi 3 kelompok berdasarkan berat badan. Penelitian ini menggunakan tiga bentuk ransum komplit, yaitu P1= Pellet, P2=Block, $\mathrm{P}_{3}=$ Silase. Hasil analisis ragam menunjukkan bahwa bentuk ransum berpengaruh nyata terhadap konsumsi bahan kering dan bahan organik, serta kecernaan bahan kering akan tetapi tidak berpengaruh nyata terhadap kecernaan bahan organik. Hasil penelitian diperoleh komsumsi bahan kering $\mathrm{P}_{1}=1,209 ; \mathrm{P} 2=1,236$ dan $\mathrm{P}_{3}=4,017 \mathrm{~kg} /$ ekor/hari, konsumsi bahan organik $\mathrm{P}_{1}=1,018 ; \mathrm{P}_{2}=1,056$ dan $\mathrm{P}_{3}=3,347 \mathrm{~kg} / \mathrm{ekor} / \mathrm{hari}$, kecernaan bahan kering $\mathrm{P}_{1}=$ 52,52; $\mathrm{P} 2=49,06$ dan $\mathrm{P}_{3}=66,44 \%$, kecernaan bahan organik $\mathrm{P} 1=62,52 ; \mathrm{P} 2=52,74$; dan $\mathrm{P}_{3}=68,12 \%$. Berdasarkan hasil penelitian dapat disimpulkan bahwa bentuk silase pada ransum komplit lebih disukai, karena memiliki konsumsi bahan kering dan bahan organik lebih tinggi dari bentuk ransum lainnya. Bentuk ransum komplit (pellet, block, dan silase) tidak berpengaruh nyata terhadap kecernaan bahan organik pada sapi bali.
\end{abstract}

Kata kunci: ransum komplit, konsumsi, kecernaan

\section{THE EFFECT OF COMPLETE FEED FORM ON THE CONSUMPTION AND DIGESTIBILITY OF DRY MATTER AND ORGANIC MATTER IN BALI CATTLE}

\begin{abstract}
Quality ration is able to provide all nutritional requirements appropriately, species, quantity, and nutrient balance for livestock. This study aims to determine the effect of complete feed form on the consumption and digestibility of dry matter and organic matter in Bali cattle. This study used 9 bali cattle divided into 3 groups based on body weight. This study uses three forms of complete ration, namely P1 = Pellet, P2 $=$ Block, $\mathrm{P}_{3}=$ Silage. The results of the analysis of variance showed that the form of ration significantly affected the consumption of dry matter and organic matter, as well as the digestibility of dry matter but did not significantly affect the digestibility of organic matter. The results obtained by the consumption of dry matter $\mathrm{P}_{1}=1.209 ; \mathrm{P}_{2}=1.236$ and $\mathrm{P}_{3}=4.017 \mathrm{~kg} /$ day $/$ head, consumption of organic matter $\mathrm{P}_{1}=$ 1.018; $\mathrm{P}_{2}=1.056$ and $\mathrm{P}_{3}=3.347 \mathrm{~kg} /$ day $/$ head, dry matter digestibility $\mathrm{P}_{1}=52.52 ; \mathrm{P}_{2}=49.06$ and $\mathrm{P}_{3}$ $=66.44 \%$, digestibility of organic matter $\mathrm{P}_{1}=62.52 ; \mathrm{P} 2=52.74 ;$ and $\mathrm{P}_{3}=68.12 \%$. Based on the results of the study it can be concluded that the form of silage in complete feed is preferred, because it has a higher consumption of dry matter and organic matter than other forms of ration. Complete form of ration (pellet, block, and silage) did not significantly affect the digestibility of organic matter in Bali cattle.
\end{abstract}

Keywords: complete feed, consumption, digestibily

\section{PENDAHULUAN}

Beternak sapi merupakan kegiatan yang sudah tidak asing lagi bagi masyarakat peternakan di Indonesia. Usaha peternakan sapi sudah dilakukan secara turuntemurun, namun masih sebagai usaha sampingan yang dikelola secara tradisional dan bersifat ekstensif. Usaha peternakan sapi yang banyak dikembangkan di Indonesia adalah peternakan sapi bali. Sapi bali merupakan sapi asli Indonesia yang memiliki ciri khas tersendiri dan berbeda dari bangsa sapi yang lain. Keunggulan sapi bali diantaranya yaitu memiliki efisiensi reproduksi yang tinggi, jarak beranak yang dekat, daging dan karkasnya berkualitas baik dan persentase karkas yang tinggi, daya tahan tubuh yang baik, cara beradaptasi dengan lingkungan, dan 
mampu menggunakan sumber pakan yang terbatas dengan baik.

Tantangan utama pengembangan sapi bali adalah ketersediaan hijauan yang tidak berkesinambungan sepanjang tahun karena pengaruh musim. Ketersediaan hijauan pada mesim hujan melimpah, sedangakan pada musim kemarau ketersediaannya akan berkurang, baik kualitas maupun kuantitasnya. Oleh karena itu, perlu dilakukan suatu inovasi untuk meningkatkan kualitas dan keterbatasan pakan. Salah satu cara yang dapat dilakukan adalah pembuatan ransum komplit dalam berbagai bentuk berupa pellet, silase, dan block.

Ransum komplit merupakan pakan yang mengandung nutrien yang cukup dalam memenuhi kebutuhan ternak, selain itu pemberiannyapun relatif mudah. Menurut pendapat Ensminger (1991) yang menyatakan bahwa penggunaan ransum komplit akan mendatangkan beberapa keuntungan antara lain : 1). meningkatkan efisiensi pemberian pakan, 2). meningkatkan konsumsi ketika hijauan kurang disukai ternak, dan 3). ransum komplit dapat mempermudah ternak untuk mendapatkan pakan yang lengkap. Dengan demikian, pembuatan ransum komplit sebagai pakan akan memudahkan dalam pemberiannya, pengangkutan dan penyimpanan. Hal ini selanjutnya akan meningkatkan produktivitas ternak dan efisiensi usaha peternakan serta kapasitas (jumlah) ternak yang dapat dipelihara oleh peternak. Penggunaan pakan komplit diharapkan mampu meningkatkan kualitas pakan dan mengatasi ketersediaan pakan serta meningkatkan komsumsi dan kecernaan terhadap pakan tersebut.

\section{METODE PENELITIAN}

\section{Materi Penelitian}

Alat yang digunakan yaitu timbangan, mesin penggiling hijauan, mesin cetakan pellet, cetakan wafer, baskom, dan peralatan pendukung pada pemeliharaan ternak sapi. Bahan yang yang digunakan yaitu ransum komplit (rumput gajah, jerami padi, jerim jagung, tongkol jagung, inokulan, dan molases) yang mempunyai kandungan protein kasar 13,29\%; lemak kasar 5,04\%; serat kasar 13,78\%; BETN 60,34\% dan $\mathrm{P}=0,69 \%$. Ternak yang digunakan adalah sapi bali.

\section{Prosedur Pembuatan Pakan Komplit}

Pembuatan ransum komplit didahului dengan mencampur rumput gajah yang telah dihaluskan dan konsentrat ditimbang dengan perbandingan 50\%:50\% dan kemudian dicampur sampai homogen. Setelah itu pakan dijadikan silase dan disimpan dalam plastik kedap udara selama 15 hari, lalu ransum komplit dibentuk sesuai perlakuan. Selanjutnya dilakukan pemeliharaan ternak yang terdiri atas 2 tahap : tahap 1 yaitu masa adaptasi dengan maksud membiasakan ternak terhadap bentuk pakan komlplit dan menghilangkan sisa-sisa dari waktu sebelumnya serta berlangsung selama 10 hari. Tahap kedua yaitu masa koleksi berlangsung selama 5 hari. Penelitian menggunakan 9 ekor sapi bali yang dibagi dalam 3 kelompok berdasarkan berat badan dan diletakkan dalam kandang metabolisme. Berat rata-rata sapi pada masing-masing kelompok adalah : kelompok $\mathrm{I}=71 \mathrm{~kg}$ $\pm 0,33 \mathrm{~kg}$, kelompok II $=90 \mathrm{~kg} \pm 0,05 \mathrm{~kg}$, kelompok $\mathrm{III}=119 \mathrm{~kg} \pm 0,75 \mathrm{~kg}$. Pemberian ransum komplit diberikan setelah ditimbang dan air minum diberikan secara ad libitum, masing-masing petak dilengkapi tempat pakan bersekat dan tempat air minum. Pada masa koleksi konsumsi diambil sebanyak 10\% dari ransum untuk menganalisis bahan kering dan bahan organik. Pada penelitian ini digunakan 3 bentuk pakan komplit perlakuan yaitu : pellet, blok, dan silase.

\section{Parameter yang Diukur dalam Penelitian}

1. Konsumsi bahan kering (g/ekor/hari)

Konsumsi BK ransum (g) = BK ransum yang diberikan (g) - BK ransum sisa (g)

2. Konsumsi bahan organik (g//ekor/hari)

Konsumsi $\mathrm{BO}$ ransum $(\mathrm{g})=\mathrm{BO}$ ransum yang diberikan (g) - BO ransum sisa (g)

3. Kecernaan bahan kering (\%)

Kecernaan BK $=\frac{\text { BK yang dikonsumsi }- \text { feses }}{\text { BK yang dikonsumsi }} \times 100 \%$

4. Kecernaan $\mathrm{BO}=\frac{\mathrm{BO} \text { yang dikonsumsi }- \text { feses }}{\text { BO yang dikonsumsi }} \times 100 \%$

Keterangan :

$\mathrm{BK}=$ bahan bering

$\mathrm{BO}=$ bahan organik

\section{Analisis Data}

Data yang diperoleh dianalisis secara statistik menggunakan rancangan acak kelompok (RAK) dengan 3 perlakuan dan 3 ulangan (Gasperz, 1994). Model matematikanya sebagai berikut :

Keterangan:

$$
Y i j=\mu+\tau i+\beta j+\epsilon i j
$$

$\mathrm{Yij}=$ Pengaruh pengamatan dari perlakuan ke-i dalam kelompok ke-j

$\mu=$ Nilai tengah populasi (population mean)

$\mathrm{i}=$ Pengaruh aditif dari perlakuan ke-i $\mathrm{i}=1,2,3,4$

$\mathrm{j}=$ Pengaruh aditif dari kelompok ke- $\mathrm{j}=1,2,3$

$\epsilon i j=$ Pengaruh galat percobaan dari perlakuan ke-i pada kelompok ke-j

Untuk mengetahui pengaruh perlakuan terhadap parameter yang diukur, data yang diperoleh dianalisis dengan sidik ragam dengan bantuan software SPSS 
ver. 16,0 (Gasperz,1994).

\section{HASIL DAN PEMBAHASAN}

Rataan konsumsi bahan kering dan bahan organik pada sapi bali yang mendapat ransum komplit bentuk pellet, blok dan silase dapat dilihat pada Tabel 1 .

Tabel 1. Rataan Konsumsi dan Kecernaan Bahan Kering dan Bahan Organik pada Sapi Bali

\begin{tabular}{cccc}
\hline \multirow{2}{*}{ Pengamatan } & \multicolumn{3}{c}{ Bentuk Ransum Komplit } \\
\cline { 2 - 4 } & P1 (Pellet) & P2 (Blok) & P3 (Silase) \\
\hline Konsumsi (kg/hari/ekor) & & & \\
-Bahan kering (BK) & $1,209^{\mathrm{a}}$ & $1,236^{\mathrm{a}}$ & $4,017^{\mathrm{b}}$ \\
-Bahan organik (BO) & $1,018^{\mathrm{a}}$ & $1,056^{\mathrm{a}}$ & $3,374^{\mathrm{b}}$ \\
Kecernaan (\%) & & & \\
-Bahan kering (BK) & $52,5^{\mathrm{b}}$ & $49,06^{\mathrm{a}}$ & $66,44^{\mathrm{b}}$ \\
-Bahan organik (BO) & $62,5^{2}$ & 52,74 & 68,12 \\
\hline
\end{tabular}

Superskrip berbeda pada baris yang sama menunjukkan perbedaan yang nyata $(P>0,05)$.

\section{Konsumsi Bahan Kering dan Bahan Organik Ternak Sapi}

Kemampuan mengkonsumsi suatu bahan pakan tunggal dapat memberikan gambaran palatabilitas pakan tersebut atau sejauh mana pakan tersebut disukai oleh ternak. Hasil analisis statistik menunjukkan bahwa bentuk ransum berpengaruh nyata terhadap konsumsi bahan kering dan bahan organik. Uji lanjut menunjukkan bahwa rataan konsumsi bahan kering dan bahan organik ransum komplit pada perlakuan $\left(\mathrm{P}_{3}\right)$ yaitu silase lebih tinggi jika dibandingkan dengan bentuk pellet (P1) dan blok (P2). Hal ini disebabkan karena pada silase lebih memiliki aroma jika dibandingkan dengan perlakuan lainnya sehingga mendapatkan palatabilitas tinggi untuk ternak. Menurut pendapat Faverdin et al. (1995) yang menyatakan bahwa palatabilitas merupakan faktor utama yang menjelaskan perbedaan konsumsi bahan kering antara pakan ternak yang berproduksi rendah. Selanjutnya dikatakan bahwa palatabilitas pakan umumnya berasosiasi dengan kecernaan yang tinggi dari suatu pakan. Palatabilitas merupakan sifat performasi bahan pakan (fisik dan kimia) yang dicerminkan oleh organoleptiknya seperti penampakan, bau, rasa (hambar, asin, masnis, pahit). Tekstur dan temperatur menimbulkan rangsangan dan daya tarik ternak untuk mengkonsumsinya (Riset dan Teknologi, 2000).

Tabel 1 menunjukkan bahwa bentuk silase mempunyai nilai konsumsi bahan organik lebih tinggi dibandingkan bentuk pellet dan blok. Hal ini disebabkan karena konsumsi bahan kering pada silase ransum komplit lebih tinggi dibandingkan bentuk pellet dan blok. Menurut Sutardi (1980) bahwa bahan organik berkaitan erat dengan bahan kering karena bahan organik merupakan bagian dari bahan kering. Menurut Chotimah (2002), konsumsi bahan kering pada ternak berbanding lurus dengan konsumsi bahan organik dari ternak tersebut. Jika konsumsi bahan keringnya tinggi, maka akan tinggi pula konsumsi bahan organiknya.

\section{Kecernaan Bahan Kering dan Bahan Organik Ternak Sapi Bali}

Kecernaan adalah awal ketersediaan berbagai nutrisi yang terkandung dalam bahan pakan tertentu bagi ternak yang mengkonsumsinya. Kecernaan yang tinggi mencerminkan besarnya sumbangan nutrien tertentu pada ternak, sementara itu pakan yang mempunyai kecernaan rendah menunjukkan bahwa pakan tersebut kurang mampu mensuplai nutrien untuk hidup pokok maupun tujuan produksi ternak.

Kecernaan bahan kering ransum komplit, blok dan silase ditunjukkan pada Tabel 1. Hasil analisis statistik menunjukkan bahwa bentuk pakan berpengaruh nyata terhadap kecernaan bahan kering ransum komplit, dari uji jarak berganda Duncan terlihat bahwa kecernaan bahan kering pada ternak ruminansia menunjukkan tingginya zat nutrisi yang dicerna terutama yang dicerna oleh mikroba rumen. Semakin tinggi nilai persentase kecernaan bahan pakan maka kualitas pakan semakin baik. Faktor-faktor yang mempengaruhi kecernaan bahan kering yaitu jumlah ransum yang dikonsumsi, laju perjalanan makanan didalam saluran pencernaan dan jenis kandungan gizi yang terkandung dalam ransum tersebut. Faktorfaktor lain yang mempengaruhi nilai kecernaan bahan kering ransum adalah tingkat proporsi bahan pakan dalam ransum, komposisi pakan, komposisi kimia, tingkat protein ransum, persentase lemak dan mineral (Tilman, et al. 1991; Anggorodi, 1994).

Pada Tabel 1 terlihat bahwa kecernaan bahan kering dan bahan organik tertinggi terdapat pada bentuk ransum silase, hal ini karena tingkat konsumsi bahan kering dan bentuk ransum silase juga tinggi yang menyebabkan kesempatan pakan untuk didegradasi dalam saluran pencernaan juga berbeda. Tillman et al. (1991) menyatakan bahwa hubungan antara daya cerna dengan konsumsi adalah bertambahnya daya cerna diikuti dengan meningkatnya konsumsi.

Hasil analisis statistik menunjukkan bahwa kecernaan bahan organik ransum komplit tidak berbeda nyata $(\mathrm{P}>0,05)$. Hal ini menunjukkan bahwa bentuk pellet, blok, dan silase mempunyai kecernaan BO yang sama pada sapi bali. Hal ini diduga karena kualitas pakan terutama kandungan protein kasar dari 3 jenis pakan relatif sama. Bamualim (1994) menyatakan bahwa protein merupakan suatu zat makanan yang esensial bagi tubuh ternak dan ketersediaan protein yang cukup menyebabkan akti- 
vitas dan pertumbuhan mikroorganisme meningkat sehingga proses pencernaan dan konsumsi juga meningkat. Lebih lanjut Oktarina et al. (2004) berpendapat bahwa peningkatan kadar protein dalam pakan akan meningkatkan laju perkembangbiakan dan populasi mikrobia rumen sehingga kemampuan mencerna pakan menjadi lebih besar. Komposisi kimia dari pakan perlakuan dapat dipengaruhi oleh daya cerna pakan. Hal ini disebabkan karena daya cerna dari suatu pakan tergantung pada keserasian dari zat-zat makanan yang terkandung didalamnya. Dilihat dari komposisi kimianya bahwa ketiga jenis pakan tersebut cukup memberikan nilai guna bagi pertumbuhan mikroorganisme rumen terutama dalam sintesis protein tubuhnya, harus tersedia cukup nitrogen. Hal ini sesuai pendapat Bamualim (1994) yang menyatakan bahwa energi merupakan faktor esensial utama yang digunakan untuk pertumbuhan mikroba rumen. Mikroba rumen menggunakan energi untuk hidup khususnya untuk melakukan transpor aktif.

Nilai kecernaan bahan kering yang dihasilkan pada penelitian ini berkisar antara 52,74-68,12\%, kecernaan bahan kering dan bahan organik tertinggi diperoleh pada ransum komplit berbentuk silase, nilai ini lebih tinggi dibandingkan hasil penelitian yang dilakukan oleh Lendrawati (2008) yang melaporkan bahwa kecernaan bahan kering silase ransum komplit berbasis hasil samping sawit pada domba ekor gemuk sebesar $64,44 \%$.

\section{SIMPULAN}

Berdasarkan dari hasil penelitian maka dapat disimpulkan bahwa bentuk silase pada ransum komplit lebih disukai sehingga bahan kering dan bahan organik lebih tinggi konsumsinya. Bentuk pakan (pellet, blok, dan silase) tidak berpengaruh terhadap kecernaan bahan organik pada sapi bali.

\section{DAFTAR PUSTAKA}

Anggorodi. 1994. Ilmu Makanan Ternak Unggas. Penerbit PT. Gramedia Pustaka Utama, Jakarta.

Bamualim, A.1994. Usaha Peternakan Sapi Bali di Nusa Tenggara Timur. Prosiding Seminar Pengolahan dan Komunikasi Hasil-Hasil Penelitian dan Aplikasi Paket Teknologi Pertanian. Sub Balai Penelitian Ternak Lili/Balai Informasi Pertanian Noelbaki kupang 1-3 Februari 1994. Hlm 17-26.

Chotimah, D. C. 2002. Kecernaan bahan kering, bahan organik, dan protein kasar ransum yang mengandung ampas teh pada kelinci persilangan lepas sapih. Skripsi. Fakultas Peternakan, Institut Pertanian Bogor, Bogor.

Ensminger, M. E.1991. Animal Science. $9^{\text {th }}$ Edition. Interstate Publisher, Inc. Danville,Illi ois

Faverdin, P., R. Baumont, dan Ingvartsen K. L. 1995. Control and Prediction of Feed Intake in Ruminants. In: M. Joernet, E. Grenet, M-H. Farce, Theriez, and C. Demarquilly (eds), Proceddings of the IV th Internasional Symposium on The Nutrition Of Herbivores. Recent Development in the Nutrition of Herbivores, INRA. Paris Pp.95-120.

Gasperz, V. 1994. Metode Perancangan Percobaan Untuk Ilmu-Ilmu Pertanian, Ilmu-Ilmu teknik dan Biologi. CV. Armico. Bandung.

Lendrawati. 2008. Kualitas fermentasi dan nutrisi silase ransum komplit hasil samping jagung, sawit dan ubi kayu. Tesis. Fakultas Pascasarjana, Institut Pertanian Bogor, Bogor.

Oktarina, K., E. Rianto, R. Adiwinarti dan A. Purnomoadi. 2004. Pemanfaatan protein pada domba ekor tipis jantan yang mendapat pakan penguat dedak padi dengan aras yang berbeda. J. Pengembangan Peternakan Tropis. Special Edition Bulan Oktober, Buku I. hlm 110-115.

Riset dan Teknologi. 2000. Pakan . Jakarta,: http:// www.ristek.go.id (17 Maret 2006)

Sutardi. 1980. Peningkatan Mutu Hasil Limbah Lignoselulosa sebagai Makanan Ternak. Fakultas Peternakan IPB, Bogor.

Tillman, A.D., H. Hartadi., S. Reksohadiprodjo.,S. Prawirokusuma., dan S. Lebdosoekodjo.1991. Ilmu Mkakan Ternak Dasar. Gadjah Mada University Press, Yogyakarta. 